\title{
Impact of serving time on the microbiological and physicochemical quality of food served during wedding banquet
}

\author{
${ }^{1}$ Ahmad, N.A., ${ }^{1, *}$ Nor-Khaizura, M.A.R., ${ }^{2}$ Mahyudin, N.A., ${ }^{1}$ Yousuf, K. and \\ ${ }^{1}$ Che Jaafar, N.Z. \\ ${ }^{1}$ Department of Food Science, Faculty of Food Science and Technology, Universiti Putra Malaysia, 43400 \\ UPM Serdang, Selangor Darul Ehsan, Malaysia \\ ${ }^{2}$ Department of Food Service \& Management, Faculty of Food Science and Technology, Universiti Putra \\ Malaysia, 43400 UPM Serdang, Selangor Darul Ehsan, Malaysia
}

\section{Article history:}

Received: 27 July 2019

Received in revised form: 15

September 2019

Accepted: 14 September 2019 Available Online: 9 October 2019

\section{Keywords:}

Microbiological quality, Caterer,

Wedding banquet

DOI:

https://doi.org/10.26656/fr.2017.4(2).267

\begin{abstract}
The aim of the present work is to investigate the microbiological quality and safety of three main dishes served during Malay wedding banquets. The two selected Malay wedding banquets were each prepared by commercial catering services and 'rewang' activity (a group of voluntary cooks from the local community) in Selangor. Three types of the dish (chicken, vegetable and cooked rice) were sampled from both banquets and analysed for Total Plate Count (TPC), Total Coliform, Escherichia coli, Staphylococcus aureus, Bacillus cereus, Salmonella, and Listeria monocytogenes. The dish samples were taken at $0,1,2,3$ and $4 \mathrm{hrs}$ after serving. For catering, the TPC for chicken, vegetable and cooked rice at $0 \mathrm{hr}$ were $6.39,6.21$ and $7.13 \log \mathrm{CFU} / \mathrm{g}$ respectively. None of the samples were contaminated with Salmonella spp. or Listeria spp. The temperature of foods during the serving times averaged between 30 to $50^{\circ} \mathrm{C}$ which was conducive for bacterial proliferation.
\end{abstract}

\section{Introduction}

Food safety is the ultimate goal in global public health of which foodborne diseases are a major threat (Velusamy et al., 2010). Food poisoning, the primary cause for foodborne diseases, is very crucial because it significantly impacts on the economic and trade of any country including Malaysia. In Malaysia, reported cases of food poisoning are increasing annually due to the suitable temperature and condition for the growth of most bacteria (Abdul-Mutalib et al., 2015). One of the sources of food poisoning that has been reported was during wedding banquets. For example, a salmonellosis outbreak causing three deaths in northern Malaysia after having a meal at a wedding banquet was reported in 2013 (Ramli, 2013).

In Malaysia, wedding banquets are prepared either by commercial catering services or rewang (voluntary food preparation by the local community at which the wedding takes place). Both categories have different methods of food preparation. For catering, the food preparation is usually indoor and within the business premises using commercial equipment and utensils whereas for rewang, food preparation is usually outdoor under makeshift tents where the locals come and go while preparing the dishes. Therefore, certain safety concerns in terms of hygienic practices might arise during rewang preparation.

One of the major concerns, when food is massprepared, is time-temperature abuse which is the primary factor for active microbial proliferation in foods. Time abuse can either be cooking the food shorter than the required duration (depending on the volume) which leads to undercooked foods, or leaving the cooked foods for a long time at room temperature (prolonged holding time), while temperature abuse is defined as cooking the foods lower than the temperature required to kill or destroy microbial contaminants. All these can inevitably increase the risk of microbial contamination (Houška et al., 2007). Improper handling during food preparation is also one of the important factors that could lead to food contamination. Poor food hygiene practices during food preparation in the kitchen have been shown to be directly related to poor microbiological quality. Furthermore, the hygiene of the utensils or equipment that come into contact with the foods also needs to be taken into great consideration. Utensils that are not properly cleaned can favour the growth of pathogenic bacteria (Nagla et al., 2014) which ultimately cause food poisoning. Therefore, the objective of this work is to determine the effect of 
serving time on the microbiological and physicochemical quality of food served and utensil used during wedding banquet.

\section{Materials and methods}

\subsection{Sample collection}

Sampling was conducted at Malay wedding banquet within Selangor area that practice the food preparation through catering and rewang (a group of voluntary cooks in the local community). The dishes that were taken are rice, chicken, and vegetables. Food samples were taken at $0,1,2,3$ and $4 \mathrm{hrs}$ during serving at the wedding banquet. The samples were put into a sterile plastic container and kept in icebox at $4^{\circ} \mathrm{C}$ before transport to the laboratory for analysis.

\subsection{Microbiological analysis}

A total of $10 \mathrm{~g}$ of each sample was homogenized in a stomacher (Stomacher Lab-Blender 400) with $90 \mathrm{~mL}$ of $0.1 \%$ peptone water. Serial dilution was prepared up to $10^{-6}$. The homogenized sample was then pipetted on Plate Count agar (PCA) for the total plate count, Mac Conkey agar for total coliform, Violet Red Bile agar (VRBA) for Escherichia coli, Baird Parker agar (BPA) for Staphylococcus aureus and Polymyxin Egg Yolk Manitol Bromothymol Blue agar (PEMBA) for Bacillus cereus. For the recovery of Salmonella spp. and Listeria spp. A total of $25 \mathrm{~g}$ of the sample was homogenized in $225 \mathrm{~mL}$ of the respective enrichment broth for each organism, buffered peptone water and Listeria enrichment broth respectively. The surface of plates and cups were collected using sterile cotton swab. A sterile cotton swab was moistened with the peptone water and rubbed to the surface of the sample. The swab was placed in the tube containing $0.1 \%$ peptone water and analyzed for the presence of total plate count (TPC). Drink sample $(250 \mathrm{~mL})$ were collected in sterile bottles and analyzed for the presence of total coliform and $E$. coli. The results were expressed as $\mathrm{CFU} / \mathrm{g}$ for food sample $\mathrm{CFU} / \mathrm{cm}^{2}$ for utensil surface and $\mathrm{CFU} / \mathrm{mL}$ for drink (BAM, 2001).

\subsection{Physicochemical analysis}

The temperature of food was taken at the time of sampling. The infrared thermometer was used by pointing at the food item with swab distance less than 30 $\mathrm{cm}$ to determine food surface and surrounding temperature. The $\mathrm{pH}$ value of food was recorded by using $\mathrm{pH}$ meter. Water activity was analyzed for each dish by using water activity meter.

\subsection{Statistical analysis}

Descriptive and statistical analysis of the data will be subjected to analysis of variance (ANOVA). A probability value of less than $5 \%$ will be defined as significant. Data of analysis will be performed using Minitab 17 statistical software (MANITAB Inc., State College, PA).

\section{Results and discussion}

\subsection{Total plate count (TPC)}

For catering, the Total Plate Count (TPC) of chicken dishes at $0,1,2,3$ and $4 \mathrm{hrs}$ after serving are presented in Table 1. There was no significant difference $(p>0.05)$ between each serving times. The data show that the microbial count increased slightly as the time after serving increased. For rewang, the TPC of chicken dishes at the $0,1,2,3$ and $4 \mathrm{hrs}$ was also not significantly different $(p>0.05)$ between each serving times (Table 1). The trend shows that the microbial load for rewang was slightly higher than catering. However, there was no significant difference $(p>0.05)$ between catering and rewang for every serving time.

For catering, the TPC of vegetable dishes at $0,1,2$, 3 and $4 \mathrm{hrs}$ after serving were presented in Table 1 . There was no significant difference $(p>0.05)$ between each serving times. For rewang, the TPC of vegetable dishes at $0,1,2,3$ and $4 \mathrm{hrs}$ after serving does not show increasing microbial load as the serving time increased. At a certain time, the microbial load decreased. For catering and rewang, the TPC of cooked rice at $0,1,2,3$ and $4 \mathrm{hrs}$ after serving were presented in Table 1 . There was no significant difference $(p>0.05)$ between each

Table 1. Total Plate Count (TPC) of chicken, vegetable and rice dishes served during wedding banquets at different serving times $(0,1,2,3$ and $4 \mathrm{hrs})$ prepared by catering and rewang.

\begin{tabular}{|c|c|c|c|c|c|c|}
\hline & \multirow{2}{*}{ Dishes } & \multicolumn{5}{|c|}{ Serving Time (Hours) } \\
\hline & & 0 & 1 & 2 & 3 & 4 \\
\hline \multirow{3}{*}{ Catering } & Chicken & $6.39 \pm 0.393^{\mathrm{a}}$ & $6.52 \pm 0.370^{\mathrm{a}}$ & $7.00 \pm 0.672^{\mathrm{a}}$ & $7.06 \pm 0.078^{\mathrm{a}}$ & $7.17 \pm 0.184^{\mathrm{a}}$ \\
\hline & Vegetable & $6.21 \pm 0.134^{\mathrm{a}}$ & $6.24 \pm 0.085^{\mathrm{a}}$ & $6.76 \pm 0.127^{\mathrm{ab}}$ & $7.15 \pm 0.213^{b}$ & $6.49 \pm 0.099^{\mathrm{a}}$ \\
\hline & Rice & $7.13 \pm 0.494^{\mathrm{a}}$ & $6.25 \pm 0.099^{\mathrm{a}}$ & $7.45 \pm 0.639^{\mathrm{a}}$ & $7.77 \pm 0.191^{\mathrm{a}}$ & $7.19 \pm 1.008^{\mathrm{a}}$ \\
\hline \multirow{3}{*}{ Rewang } & Chicken & $6.54 \pm 0.032^{\mathrm{a}}$ & $7.71 \pm 1.032^{\mathrm{a}}$ & $7.84 \pm 0.993^{\mathrm{a}}$ & $7.78 \pm 0.627^{\mathrm{a}}$ & $6.46 \pm 0.198^{\mathrm{a}}$ \\
\hline & Vegetable & $6.13 \pm 0.139^{\mathrm{ab}}$ & $5.38 \pm 0.077^{\mathrm{b}}$ & $7.47 \pm 0.011^{\mathrm{ac}}$ & $7.80 \pm 0.087^{\mathrm{ac}}$ & $5.95 \pm 0.920^{\mathrm{a}}$ \\
\hline & Rice & $7.63 \pm 0.516^{\mathrm{a}}$ & $8.30 \pm 0.315^{\mathrm{ab}}$ & $9.13 \pm 0.136^{b}$ & $9.34 \pm 0.034^{b}$ & $9.011 \pm 0.153^{b}$ \\
\hline
\end{tabular}

Different superscripts indicate significant difference between columns. 
serving times. The results for both catering and rewang showed high count of TPC which were between $6 \mathrm{log}$ $\mathrm{CFU} / \mathrm{g}$ and $9 \log \mathrm{CFU} / \mathrm{g}$. These counts were above the maximum limit permitted by Malaysian Food Act 1983 and Food Regulation 1985 which is $<6 \log \mathrm{CFU} / \mathrm{g}$. It is also noteworthy that the TPC for rewang was slightly higher compared to the catering in all the dishes tested.

There was a significant difference $(p<0.05)$ in TPC for vegetable dishes between catering and rewang after 1 and 2 hrs of serving. Many factors can contribute to this trend. Rewang is usually prepared outdoor and this could lead to the increase in the risk of food poisoning due to many people involved, lack of accommodation, frequent use of temporary staff, less efficient storage facilities, lack of clean water supply and potential exposure to extreme weather condition which favour bacterial growth (Willis et al., 2012).

Across the serving times ( 0 to $4 \mathrm{hrs}$ ), TPC for catering showed an increasing trend. This might be due to temperature abuse. The temperature during serving was not controlled and the foods were left at room temperature for a long time. The growth of bacteria is generally favoured at temperature between $5^{\circ} \mathrm{C}$ and $60^{\circ}$ C. According to WHO (2006), cooked foods must not be served at room temperature for more than two hours. Keeping cooked foods at room temperature for a long time can increase the risk of food contamination (Houška et al., 2007).

The contamination of foods might be due to temperature abuse during serving. Hot foods should be served hot $\left(\geq 60^{\circ} \mathrm{C}\right.$; or kept in a warmer) and cold foods should be served cold (WHO, 2006). Based on the observation at the wedding banquets, the foods were merely served in containers without temperature control. High load of TPC might also be due to the poor personal hygiene of the food handlers. In the previous study, Walker et al. (2003) reported that the common mistake made by the catering services during cooking, cooling and re-heating phases of foods are personal hygiene failures, cross-contamination, poor food handling and temperature abuse.

\subsection{Total coliform}

For catering, the total coliform (TC) of chicken dishes at $0,1,2,3$ and 4 hrs after serving were presented in Table 2. A chicken dish at $4 \mathrm{hrs}$ has the highest TC which is $7.03 \log \mathrm{CFU} / \mathrm{g}$. For rewang, the TC of chicken dishes at $0,1,2,3$ and $4 \mathrm{hrs}$ after serving showed no significant difference $(p>0.05)$ for the TC in chicken dish for rewang at 0 until $4 \mathrm{hrs}$ after serving time. There was however a significant difference $(p<0.05)$ for chicken dishes between catering and rewang at 0,2 and $3 \mathrm{hrs}$ after serving.

For catering, the TC of vegetable dishes at $0,1,2,3$ and $4 \mathrm{hrs}$ after serving were presented in Table 2 . There was a significant difference $(p<0.05)$ on the TC between 0 and $1 \mathrm{hr}$ after serving and no significant difference $(p>0.05)$ between 2,3 and 4 hrs after serving. For rewang, the TC of vegetable dishes at $0,1,2,3$ and $4 \mathrm{hrs}$ after serving showed a significant difference $(p<0.05)$ for vegetable dishes between catering and rewang at 0,1 and 2 hrs after serving.

Detection of Total Coliform (TC) is used as a hygienic indicator. The high level of TC indicates that the food is not hygienic or poor hygiene is practiced during its preparation (Kornacki and Johnson, 2001). High TC results at early serving (0 hours) observed in the present work could be related to unhygienic food processing and handling. The TC for all dishes analysed (chicken, vegetable and rice) were higher than the regulatory limit $\left(<10^{2} \mathrm{CFU} / \mathrm{g}\right.$; European Commission Regulation, 2007). The presence of coliforms and E. coli in food samples indicates that the food handlers' personal hygiene practice is poor and crosscontamination of utensils could easily occur during food preparation (Hasan et al., 2004; Yousif et al., 2013). Thus, the food handlers' personal hygiene and crosscontamination precaution should be improved to minimise the growth of foodborne bacteria (Hasan et al., 2004).

\subsection{Escherichia coli}

For catering, the E. coli count of chicken dishes at 0 ,

Table 2. Total Coliform (TC) of chicken, vegetable and rice dishes served during wedding banquets at different serving times $(0$, $1,2,3$ and $4 \mathrm{hrs}$ ) prepared by catering and rewang.

\begin{tabular}{ccccccc}
\hline \multirow{2}{*}{ Dishes } & \multicolumn{5}{c}{ Serving Time (Hours) } \\
\cline { 3 - 6 } & & 0 & 1 & 2 & 3 & 4 \\
\hline \multirow{3}{*}{ Catering } & Chicken & $4.00 \pm 0.000^{\mathrm{a}}$ & $5.98 \pm 0.458^{\mathrm{b}}$ & $6.81 \pm 0.00^{\mathrm{c}}$ & $5.00 \pm 0.000^{\mathrm{d}}$ & $7.03 \pm 0.049^{\mathrm{c}}$ \\
& Vegetable & $6.18 \pm 0.035^{\mathrm{a}}$ & $4.00 \pm 0.000^{\mathrm{b}}$ & $5.00 \pm 0.000^{\mathrm{c}}$ & $5.74 \pm 0.368^{\mathrm{ac}}$ & $5.57 \pm 0.382^{\mathrm{ac}}$ \\
& Rice & $5.94 \pm 0.141^{\mathrm{ab}}$ & $5.60 \pm 0.424^{\mathrm{b}}$ & $7.14 \pm 0.478^{\mathrm{ab}}$ & $7.39 \pm 0.545^{\mathrm{a}}$ & $6.68 \pm 0.290^{\mathrm{ab}}$ \\
\hline \multirow{3}{*}{ Rewang } & Chicken & $6.39 \pm 0.125^{\mathrm{a}}$ & $6.03 \pm 0.520^{\mathrm{a}}$ & $6.22 \pm 0.083^{\mathrm{a}}$ & $6.65 \pm 0.383^{\mathrm{a}}$ & $6.39 \pm 0.762^{\mathrm{a}}$ \\
& Vegetable & $5.14 \pm 0.139^{\mathrm{a}}$ & $5.38 \pm 0.078^{\mathrm{a}}$ & $6.00 \pm 0.000^{\mathrm{b}}$ & $6.45 \pm 0.000^{\mathrm{c}}$ & $6.00 \pm 0.000^{\mathrm{b}}$ \\
& Rice & $7.43 \pm 0.753^{\mathrm{a}}$ & $8.93 \pm 0.000^{\mathrm{a}}$ & $8.24 \pm 0.203^{\mathrm{a}}$ & $8.02 \pm 0.383^{\mathrm{a}}$ & $7.52 \pm 0.144^{\mathrm{a}}$ \\
\hline
\end{tabular}

Different superscripts indicate significant difference between columns. 
Table 3. E. coli count of chicken, vegetable and rice dishes served during wedding banquets at different serving times $(0,1,2,3$ and $4 \mathrm{hrs}$ ) prepared by catering and rewang.

\begin{tabular}{ccccccc}
\hline \multirow{2}{*}{ Dishes } & \multicolumn{5}{c}{ Serving Time (Hours) } \\
\cline { 3 - 6 } & & 0 & 1 & 2 & 3 & 4 \\
\hline \multirow{3}{*}{ Catering } & Chicken & $5.39 \pm 0.125^{\mathrm{a}}$ & $6.43 \pm 0.601^{\mathrm{a}}$ & $6.55 \pm 0.088^{\mathrm{a}}$ & $6.15 \pm 0.212^{\mathrm{a}}$ & $5.40 \pm 0.000^{\mathrm{a}}$ \\
& Vegetable & $4.00 \pm 0.000^{\mathrm{a}}$ & $5.29 \pm 0.297^{\mathrm{b}}$ & $6.00 \pm 0.000^{\mathrm{c}}$ & $6.76 \pm 0.106^{\mathrm{d}}$ & $7.78 \pm 0.057^{\mathrm{e}}$ \\
& Rice & $6.66 \pm 0.919^{\mathrm{a}}$ & $5.87 \pm 0.297^{\mathrm{b}}$ & $6.50 \pm 0.254^{\mathrm{ab}}$ & $6.77 \pm 0.134^{\mathrm{a}}$ & $6.75 \pm 0.05^{\mathrm{a}}$ \\
\hline \multirow{3}{*}{ Rewang } & Chicken & $6.51 \pm 0.491^{\mathrm{a}}$ & $6.60 \pm 0.289^{\mathrm{a}}$ & $7.57 \pm 0.743^{\mathrm{a}}$ & $6.50 \pm 0.516^{\mathrm{a}}$ & $6.54 \pm 0.518^{\mathrm{a}}$ \\
& Vegetable & $6.36 \pm 0.509^{\mathrm{a}}$ & $5.89 \pm 0.834^{\mathrm{a}}$ & $5.00 \pm 0.000^{\mathrm{a}}$ & $5.54 \pm 0.338^{\mathrm{a}}$ & $6.24 \pm 0.337^{\mathrm{a}}$ \\
& Rice & $6.65 \pm 0.042^{\mathrm{a}}$ & $7.49 \pm 0.000^{\mathrm{b}}$ & $8.29 \pm 0.156^{\mathrm{b}}$ & $8.70 \pm 0.423^{\mathrm{b}}$ & $8.41 \pm 0.689^{\mathrm{b}}$ \\
\hline
\end{tabular}

Different superscripts indicate significant difference between columns.

1, 2, 3 and 4 hrs after serving were presented in Table 3. There was no significant difference $(p>0.05)$ between each serving times. For catering, the $E$. coli count of vegetable dishes at $0,1,2,3$ and $4 \mathrm{~h}$ after serving were presented in Table 3 . There was a significant difference $(p<0.05)$ between each serving times. For rewang, the $E$. coli count of vegetable dishes at $0,1,2,3$ and $4 \mathrm{hrs}$ after serving showed no significant difference $(p>0.05)$ between each serving times.

For catering, the $E$. coli count of cooked rice at 0,1 , 2,3 and $4 \mathrm{hrs}$ after serving were 6.66, 5.87, 6.50, 6.77 and $6.75 \log \mathrm{CFU} / \mathrm{g}$, respectively. There was a significant difference $(p>0.05)$ between 0,1 and $2 \mathrm{hrs}$ after serving but none between 3 and 4 hrs. For rewang, the $E$. coli count of cooked rice at $0,1,2,3$ and $4 \mathrm{hrs}$ after serving were $6.65,7.49,8.29,8.70$ and $8.41 \log$ $\mathrm{CFU} / \mathrm{g}$, respectively. There was no significant difference ( $p>0.05$ ) between $0,2,3$ and 4 hrs. This might be due to the temperature abuse occurring during serving. For catering after $0 \mathrm{~h}$, the count was already high. This might be due to improper handling during cooking and also temperature abuse during delivery. Delivery proses can also increase the risk of contamination if the proper procedure of delivery is not applied.

\subsection{Staphylococcus aureus}

$S$. aureus was detected at early serving ( $0 \mathrm{hr})$ for both catering and rewang (Table 4). The contamination might come from the food preparation due to poor handling practice. Personal hygiene and environmental sanitation are key factors in the transmission of foodborne diseases by transferring the pathogenic bacteria through faecal-oral route or skin contact as well as the hygiene of kitchen surrounding and utensils (Linscott, 2011; Bajzík et al., 2012). Other researchers found that having poor attitude during food handling could lead to poor hygiene practice (Howells et al., 2008). The results show inconsistent trend possibly due to re-introduction of bacteria into food during serving times.

\subsection{Bacillus cereus}

For catering, B. cereus count of cooked rice at 0,1 , 2, 3 and 4 hrs after serving were presented in Table 5. There was a significant difference $(p<0.05)$ between 0 , 1 and 2 hrs. For rewang, the $B$. cereus count of cooked rice at $0,1,2,3$ and $4 \mathrm{hrs}$ after serving were significant difference $(p<0.05)$ between 0,1 and $3 \mathrm{hrs}$. There was also significant difference $(p<0.05)$ between catering and rewang for every serving hour except for $4 \mathrm{hrs}$.

Table 4. S. aureus count of chicken, vegetable and rice dishes served during wedding banquets at different serving times $(0,1,2$, 3 and $4 \mathrm{hrs}$ ) prepared by catering and rewang.

\begin{tabular}{ccccccc}
\hline \multirow{2}{*}{ Dishes } & \multicolumn{5}{c}{ Serving Time (Hours) } \\
\cline { 3 - 7 } & Chicken & $4.65 \pm 0.920^{\mathrm{a}}$ & $4.85 \pm 0.212^{\mathrm{a}}$ & $5.00 \pm 0.000^{\mathrm{a}}$ & $7.00 \pm 0.000^{\mathrm{b}}$ & $5.24 \pm 0.332^{\mathrm{ab}}$ \\
\hline \multirow{3}{*}{ Catering } & Vegetable & $4.00 \pm 0.000^{\mathrm{a}}$ & $5.00 \pm 0.000^{\mathrm{ab}}$ & $5.50 \pm 0.707^{\mathrm{ab}}$ & $5.65 \pm 0.495^{\mathrm{b}}$ & $5.39 \pm 0.127^{\mathrm{ab}}$ \\
& Rice & $5.65 \pm 0.919^{\mathrm{a}}$ & $5.50 \pm 0.707^{\mathrm{a}}$ & $6.15 \pm 1.626^{\mathrm{a}}$ & $6.80 \pm 0.707^{\mathrm{a}}$ & $6.63 \pm 1.626^{\mathrm{a}}$ \\
\hline \multirow{3}{*}{ Rewang } & Chicken & $6.09 \pm 0.098^{\mathrm{a}}$ & $6.54 \pm 0.085^{\mathrm{a}}$ & $6.00 \pm 0.000^{\mathrm{a}}$ & $5.24 \pm 0.339^{\mathrm{b}}$ & $5.00 \pm 0.000^{\mathrm{b}}$ \\
& Vegetable & $5.39 \pm 0.127^{\mathrm{a}}$ & $5.30 \pm 0.028^{\mathrm{a}}$ & $6.15 \pm 0.212^{\mathrm{b}}$ & $5.69 \pm 0.297^{\mathrm{ab}}$ & $5.00 \pm 0.000^{\mathrm{a}}$ \\
& Rice & $5.14 \pm 0.134^{\mathrm{a}}$ & $6.91 \pm 1.041^{\mathrm{ab}}$ & $6.96 \pm 0.364^{\mathrm{ab}}$ & $7.39 \pm 0.166^{\mathrm{b}}$ & $8.18 \pm 0.206^{\mathrm{b}}$ \\
\hline
\end{tabular}

Different superscripts indicate significant difference between columns.

Table 5. B. cereus count of rice dishes served during wedding banquets at different serving times (0, 1, 2, 3 and 4 hours) prepared by catering and rewang.

\begin{tabular}{lcccccc}
\hline & \multirow{2}{*}{ Samples } & \multicolumn{5}{c}{ Serving Time (Hours) } \\
\cline { 3 - 7 } & & 0 & 1 & 2 & 3 & 4 \\
\hline Catering & Rice & $5.17 \pm 0.184^{\mathrm{ab}}$ & $5.00 \pm 0.000^{\mathrm{b}}$ & $6.80 \pm 0.141^{\mathrm{c}}$ & $6.00 \pm 0.000^{\mathrm{ac}}$ & $6.30 \pm 0.417^{\mathrm{c}}$ \\
Rewang & Rice & $7.15 \pm 0.022^{\mathrm{ac}}$ & $7.37 \pm 0.105^{\mathrm{a}}$ & $6.00 \pm 0.000^{\mathrm{b}}$ & $7.09 \pm 0.127^{\mathrm{ac}}$ & $6.93 \pm 0.035^{\mathrm{c}}$ \\
\hline
\end{tabular}

Different superscripts indicate significant difference between columns. 
The obtained results show that $B$. cereus counts were high in cooked rice samples for both catering and rewang. B. cereus spores are heat and acid resistance thus, cannot be eliminated by normal sanitation processes or pasteurisation (Ehling-Schulz and Messelhäusser, 2012). Therefore, the presence of $B$. cereus spores could survive during cooking and germinate during holding (Mosupye and Holy, 2000). Usually, cooked rice is stored in a flask or covered container which can maintain the temperature of the cooked rice. But, based on the observation during the wedding banquets, some of the guests did not re-cover the container with its lid after taking the cooked rice. Thus, temperature abuse might have occurred. This will become a major problem in mass catering if the temperature management is poor (Ehling-Schulz and Messelhäusser, 2012). Pathogenic spores must not be allowed to germinate and multiply to keep the food safe during serving (FDA, 2001).

\subsection{Salmonella spp. and Listeria spp.}

Salmonella spp. and Listeria spp. were not detected in any of the three dishes sampled from both catering and rewang. Listeria spp. and Salmonella spp. are pathogenic bacteria that must not be present in food samples. Salmonella spp. is one of the important factors in foodborne diseases. Salmonella enterica serovar Typhi infection can happen when infected food handler improperly handles the food (Newell et al., 2010).

\subsection{Microbiological quality of drink}

Table 6 shows the microbial counts of drinks served during the wedding banquets prepared by catering and rewang. Detection of coliforms is used as an indicator of sanitary quality of water used or as a general indicator of the sanitary condition in the food processing environment (Feng et al., 2002). The presence of coliform indicates that there may be a problem with the quality of water or possible contamination during the process (FSAI, 2011). The previous study by Jamal et al. (2014) revealed that most of the drinking water obtained from a restaurant in Bangladesh was contaminated with high Total Plate Count and also Total Coliform. This might be due to the lack of microbial safety practice. The data obtained in the present work were categorised as unsatisfactory because $E$. coli was detected in the drink samples from both catering and rewang. All drink samples showed high presence of coliforms which was far above the regulatory limits prescribed in the Drinking Water Quality Standard of Malaysia, (2004). This indicates poor safety and quality of the drinks being served. The presence of $E$. coli in drink samples might indicate that the water had been faecally-contaminated, or the food handlers did not boil the water before used in cooking (Musico, 2017).

Table 6. Microbial counts of drink samples from wedding banquets prepared by catering and rewang

\begin{tabular}{ccc}
\hline & Parameters & Log CFU $/ \mathrm{mL}$ \\
\hline \multirow{2}{*}{ Catering } & Total Coliform & 4.40 \\
& E. coli & 3.08 \\
\hline \multirow{2}{*}{ Rewang } & Total Coliform & 3.10 \\
& E. coli & 1.65 \\
\hline
\end{tabular}

3.8 Microbiological quality of utensil used during serving

Table 7 shows the bacterial contamination of the surfaces of plates and cups used during the wedding banquets. The Total Plate Count was used as a parameter for microbiological quality of utensils for both catering and rewang. The data show that the counts were in the range of $\log 3$ to $4 \mathrm{CFU} / \mathrm{cm}^{2}$. Improper sanitisation and storage of the utensils can contribute to bacterial contamination (Edema and Omemu, 1992) as well as using utensils that are already worn out (Nagla et al., 2014). The method to clean the utensils is therefore important to minimise bacterial contamination. Limited time is a factor that influences hygienic quality practice such as washing hands, washing utensils and also checking the temperature of the foods (Howells et al., 2008). The utensils must be cleaned using warm water and detergent followed by disinfectant to minimise contamination (Barker et al., 2003).

Table 7. Total Plate Count of utensils used during wedding banquets prepared by catering and rewang

\begin{tabular}{lccc}
\hline & & Samples & Log CFU $/ \mathrm{cm}^{2}$ \\
\hline \multirow{2}{*}{ Catering } & \multirow{2}{*}{ Total plate count } & Cup & 4.09 \\
& & Plate & 4.31 \\
\hline \multirow{2}{*}{ Rewang } & \multirow{2}{*}{ Total plate count } & Cup & 4.26 \\
& & Plate & 3.38 \\
\hline
\end{tabular}

3.9 Physicochemical of food served during wedding banquet

\subsubsection{Temperature}

Table 8 shows the food temperatures recorded during the serving times. For catering, chicken dishes showed the lowest temperature range of $20^{\circ} \mathrm{C}$ to $30^{\circ} \mathrm{C}$. For vegetable dishes and cooked rice, the temperature range was $30^{\circ} \mathrm{C}$ to $40^{\circ} \mathrm{C}$. The observed temperatures were in fact in the microbial danger zone $\left(5^{\circ} \mathrm{C}\right.$ to $60^{\circ} \mathrm{C}$ ) (USDA, 2011) which favours rapid bacterial growth. There was no significant difference $(p>0.05)$ between each serving time for all food samples. For rewang, the temperatures for chicken and vegetable dishes were around $38^{\circ} \mathrm{C}$ to $60^{\circ} \mathrm{C}$. For cooked rice, the temperatures were around $38^{\circ}$ $\mathrm{C}$ to $50^{\circ} \mathrm{C}$. Here, the temperatures were also within the danger zone which could lead to bacterial growth. Cooked food must not be left at room temperature for more than two hours (WHO, 2006). Keeping cooked 
Table 8. Temperatures recoded for food samples at different serving times during wedding banquets prepared by catering and rewang

\begin{tabular}{ccccccc}
\hline & \multicolumn{5}{c}{ Temperature $\left({ }^{\circ} \mathrm{C}\right)$} \\
\cline { 3 - 6 } & Dishes & \multicolumn{5}{c}{ Serving time (hours) } \\
\cline { 3 - 6 } & & 0 & 1 & 2 & 3 & 4 \\
\cline { 3 - 6 } Catering & Chicken & $29.35^{\mathrm{a}}$ & $31.40^{\mathrm{a}}$ & $30.75^{\mathrm{a}}$ & $28.95^{\mathrm{a}}$ & $28.05^{\mathrm{a}}$ \\
& Vegetable & $40.05^{\mathrm{a}}$ & $32.55^{\mathrm{a}}$ & $38.45^{\mathrm{a}}$ & $35.05^{\mathrm{a}}$ & $30.35^{\mathrm{a}}$ \\
& Rice & $42.80^{\mathrm{a}}$ & $36.60^{\mathrm{a}}$ & $40.60^{\mathrm{a}}$ & $44.60^{\mathrm{a}}$ & $32.90^{\mathrm{a}}$ \\
\hline \multirow{3}{*}{ Rewang } & Chicken & $48.20^{\mathrm{a}}$ & $48.50^{\mathrm{a}}$ & $50.00^{\mathrm{a}}$ & $41.60^{\mathrm{a}}$ & $38.30^{\mathrm{a}}$ \\
& Vegetable & $57.40^{\mathrm{a}}$ & $59.90^{\mathrm{a}}$ & $51.80^{\mathrm{a}}$ & $44.80^{\mathrm{a}}$ & $43.60^{\mathrm{a}}$ \\
& Rice & $38.40^{\mathrm{a}}$ & $39.40^{\mathrm{a}}$ & $38.60^{\mathrm{a}}$ & $38.10^{\mathrm{a}}$ & $44.50^{\mathrm{a}}$ \\
\hline
\end{tabular}

Different superscripts indicate significant difference between columns.

Table 9. $\mathrm{pH}$ and water activity for food samples at different serving times during wedding banquets prepared by catering and rewang

\begin{tabular}{llcccccc}
\hline \multirow{2}{*}{ Dishes } & \multicolumn{5}{c}{$\mathrm{pH}$} & \multirow{2}{*}{ Water activity } \\
\cline { 3 - 6 } & & \multicolumn{5}{c}{ Serving time (hours) } & \\
\cline { 3 - 7 } & Chicken & $6.16^{\mathrm{a}}$ & $6.06^{\mathrm{a}}$ & $6.07^{\mathrm{a}}$ & $6.06^{\mathrm{a}}$ & $6.20^{\mathrm{a}}$ & 0.988 \\
\multirow{3}{*}{ Catering } & Vegetable & $5.70^{\mathrm{a}}$ & $5.58^{\mathrm{a}}$ & $5.56^{\mathrm{a}}$ & $5.42^{\mathrm{a}}$ & $5.48^{\mathrm{a}}$ & 0.991 \\
& Rice & $6.72^{\mathrm{a}}$ & $6.76^{\mathrm{a}}$ & $6.73^{\mathrm{a}}$ & $6.78^{\mathrm{a}}$ & $6.69^{\mathrm{a}}$ & 0.996 \\
\hline \multirow{3}{*}{ Rewang } & Chicken & $6.55^{\mathrm{a}}$ & $6.43^{\mathrm{ab}}$ & $6.21^{\mathrm{bc}}$ & $6.29^{\mathrm{bc}}$ & $6.27^{\mathrm{bc}}$ & 0.996 \\
& Vegetable & $5.00^{\mathrm{a}}$ & $4.99^{\mathrm{a}}$ & $5.05^{\mathrm{a}}$ & $5.25^{\mathrm{a}}$ & $5.00^{\mathrm{a}}$ & 0.989 \\
& Rice & $5.92^{\mathrm{a}}$ & $6.03^{\mathrm{a}}$ & $6.09^{\mathrm{a}}$ & $6.37^{\mathrm{a}}$ & $6.13^{\mathrm{a}}$ & 0.998 \\
\hline
\end{tabular}

Different superscripts indicate significant difference between columns.

food at room temperature for a long time can increase the risk of food contamination (Houška et al., 2007) because bacteria can multiply rapidly at this temperature.

\section{9. $2 \mathrm{pH}$ value and water activity $\left(a_{w}\right)$}

Table 9 shows the $\mathrm{pH}$ and water activity $\left(\mathrm{a}_{\mathrm{w}}\right)$ of the food samples obtained from wedding banquets prepared by catering and rewang. The $\mathrm{pH}$ of food samples was between 4 to 6 . Vegetable dishes for both catering and rewang had the lowest $\mathrm{pH}(4-5)$ which is expected since the dish contained pineapple (acidic). The $\mathrm{pH}$ obtained from the food samples were highly suitable for the growth of most microorganisms. Some foodborne bacteria such as E. coli, $S$. aureus and Salmonella spp. require minimum $\mathrm{pH}$ around 4 (Jay et al., 2005). All the food samples evaluated had $a_{w}$ nearing 1.0 which was highly favourable for bacterial growth. Spoilage bacteria favour the growth $\mathrm{a}_{\mathrm{w}}>0.91$ (Jay et al., 2005).

\section{Conclusion}

The study has found that the dishes (chicken, vegetable and rice) from both catering and rewang had high microbial contamination at each serving time $(0,1$, 2, 3 and $4 \mathrm{hrs}$ ) evaluated. These results are considered unsatisfactory in terms of food safety. The finding also shows that the dishes had high microbial contamination as early as $0 \mathrm{hr}$ after serving which might indicate that the contamination had occurred earlier during food preparation. The microbial loads show an increasing trend with some degrees of fluctuation during the four hours serving time. The temperature abuse during the serving time could be one of the major factors contributing to the high microbial load. The temperatures of dishes during the serving times were observed to be within the temperature danger zone (TDZ) of 5 to $60^{\circ} \mathrm{C}$. However, the dishes served were free from Salmonella spp. and Listeria spp.

\section{Conflict of Interest}

The authors declare that they have no competing interests.

\section{Acknowledgements}

This work was supported by Insentif Putra Muda (IPM) research grant, GP-IPM/2014/9434100. The authors would like to acknowledge the Food Microbiology Research Laboratory, Faculty of Food Science and Technology, University Putra Malaysia.

\section{References}

Abdul-Mutalib, N.-A., Abdul-Rashid, M.-F., Mustafa, S., Amin-Nordin, S., Hamat, R.A. and Osman, M. (2012). Knowledge, attitude and practices regarding food hygiene and sanitation of food handlers in Kuala Pilah, Malaysia. Food Control, 27(2), 289293. https://doi.org/10.1016/j.foodcont.2012.04.001

Bajzík, P., Bobkov, A., Bobko, M., Zeleňáková, L., Lopašovský, L'. and Čapla, J. (2012). Ratings of the hygienic conditions and verification professional competence employee in common food services. 
Journal of Microbiology, Biotechnology and Food Sciences, 1, 717-724.

BAM. (2001). Bacteriological Analytical Manual Online. Retrieved from FDA BAM website: https:// www.fda.gov/food/laboratory-methods-food/ bacteriological-analytical-manual-bam

Barker, J., Naeeni, M. and Bloomfield, S.F. (2003). The effects of cleaning and disinfection in reducing Salmonella contamination in a laboratory model kitchen. Journal of Applied Microbiology, 95(6), 1351-1360. 2672.2003.02127.x

Edema M.O. and Omemu. A.M. (1992). Microbiology and food hygiene in public food services. Proceedings of the International Conference on Science and National Development, Abeokuta, October 25 - 28, 2004.

Ehling-Schulz, M. and Messelhäusser, U. (2012). One pathogen but two different types of foodborne outbreak: Bacillus cereus in catering facilities in Germany. In Hoorfar, J. (Ed.). Case Studies in Food Safety and Authenticity. Lessons from Real-Life Situations. USA: Woodhead Publishing Limited. https://doi.org/10.1533/9780857096937.1.63

Feng, P., Weagant, S., Grant, M. and Burkhardt, W. (2002). BAM 4: Enumeration of Escherichia coli and the Coliform Bacteria. Retrieved from FDA BAM website: https://www.fda.gov/food/laboratorymethods-food/bam-4-enumeration-escherichia-coliand-coliform-bacteria

Food and Drug Administration, FDA (2001). Food Code, U.S. Public Health Service, U.S. Department of Health and Human Services. Retrieved from FDA website: https://www.fda.gov/ohrms/dockets/98fr/ FDAFoodCode2001.pdf

Food Safety Authority of Ireland, FSAI (2011), Microbiological Safety of Bottled Water (10NS2), Retrieved from FSAI website: https://www.fsai.ie/ WorkArea/DownloadAsset.aspx?id=11085.

Houška M., Kýhos K., Landfeld A., Průchová J., Schlemmerová L., Šmuhařová H. and Špelina V.N.P. (2007). Dry heat inactivation of Bacillus cereus in rice. Czech Journal of Food Sciences, 25(4), 208213. https://doi.org/10.17221/692-CJFS

Howells, A.D., Roberts, K.R., Shanklin, C.W., Pilling, V.K., Brannon, L.A. and Barrett, B.B. (2008). Restaurant employees' perceptions of barriers to three food safety practices. Journal of the American Dietetic Association, 108(8), 1345-1349. https:// doi.org/10.1016/j.jada.2008.05.010

Jamal, R., Alam, S.M.S. and Moniruzzaman, M. (2014). Comparison of microbiological and physicochemical quality of tap and dispenser water from different mid -range restaurants of Dhaka City. Bangladesh Journal of Microbiology, 31(1), 69-72.

Jay, J.M., Martin J.L. and David A.G. (Eds.). (2005). Modern Food Microbiology. USA: Springer.

Kornacki, J.L. and Johnson, J.L. (2010) Enterobacteriaceae, coliforms, and Escherichia coli as quality and safety indicators. In Downes, F.P. and Ito, K. (Ed.). Compendium of methods for the microbiological examination of foods. $4^{\text {th }}$ ed. Washington, DC., USA: American Public Health Association (APHA).

Linscott, A.J. (2011). Food-borne illnesses. Clinical Microbiology Newsletter, 33(6), 41-45. https:// doi.org/10.1016/j.clinmicnews.2011.02.004

Mosupye, F.M. and Holy, A.V. (2000). Microbiological hazard identification and exposure assessment of street food vending in Johannesburg, South Africa. International Journal of Food Microbiology, 61(23), 137-145. https://doi.org/10.1016/S0168-1605(00) 00264-6

Newell, D.G., Koopmans, M., Verhoef, L., Duizer, E., Aidara-Kane, A., Sprong, H. and Kruse, H. (2010). Food-borne diseases - the challenges of 20 years ago still persist while new ones continue to emerge. International Journal of Food Microbiology, 139, S3 $-\mathrm{S} 15$. https://doi.org/10.1016/ j.ijfoodmicro.2010.01.021

Ramli, S. (2013). Tiga maut keracunan makanan. Utusan Online, Retrieved from http://ww1.utusan.com.my/ utusan/Jenayah/20131001/je_01/Tiga-mautkeracunan-makanan

United States Department of Agriculture, USDA. (2011). "Danger Zone"(40 $\left.{ }^{\circ} \mathrm{F}-140{ }^{\circ} \mathrm{F}\right)$. Retrieved from USDA website: https://www.fsis.usda.gov/shared/ PDF/Danger_Zone.pdf.

Velusamy, V., Arshak, K., Korostynska, O., Oliwa, K. and Adley, C. (2010). An overview of foodborne pathogen detection: in the perspective of biosensors. Biotechnology Advances, 28(2), 232-254. https:// doi.org/10.1016/j.biotechadv.2009.12.004

Walker, E., Pritchard, C. and Forsythe, S. (2003). Food handlers' hygiene knowledge in small food businesses. Food Control, 14(5), 339-343. https:// doi.org/10.1016/S0956-7135(02)00101-9

Willis, C., Elviss, N., Aird, H., Fenelon, D. and McLauchlin, J. (2012). Evaluation of hygiene practices in catering premises at large-scale events in the UK: Identifying risks for the Olympics 2012. Public Health, 126(8), 646-656. https:// doi.org/10.1016/j.puhe.2012.04.007

World Health Organisation, WHO. (2006). Five keys to 
safer food manual. Retrieved from WHO website: http://www.who.int/foodsafety/publications/

$\simeq \quad$ consumer/manual_keys.pdf

Yousif, E.I., Ashoush, I.S., Donia, A.A. and Hala Goma, K.A. (2013). Critical control points for preparing chicken meals in a hospital kitchen. Annals of Agricultural Sciences, 58(2), 203-211. https:// doi.org/10.1016/j.aoas.2013.07.004 